\title{
Peace Education Initiative in Nepal: Redressing the Value of 'Celebrating Diversity'
}

\author{
Raj Kumar Dhungana \\ Kathmandu University, School of Education \\ rajkumar@kusoed.edu.np
}

\begin{abstract}
In a multicultural society, education can both foster the value of 'celebrating diversity' and thereby the social harmony but it can also foster social tensions and fuel conflicts by promoting cultural homogenisation. Using content analysis of education policies, curriculum and textbooks this study examined the way Nepal's historical education system shifted from monocultural education towards a multicultural peace education approach. This study revealed that, by including the contents that promote multicultural values, the critical peace education initiative contributes to redress the socio-political tensions that the monocultural education system fuelled historically. However, the local ownership, longer term commitment of the stakeholders, and regular consultations with the representatives of different cultural groups in curricular reform are essential for a successful peace education initiative.
\end{abstract}

\section{Introduction}

Nepal is a multicultural country of over 26.5 million inhabitants spread across 125 castes or ethnic groups speaking 123 languages and following 10 religions (Central Bureau of Statistics (CBS), 2012). The population group can be classified into two broad categories: about 50 per cent of the population lives in the hills or high mountains including valleys, and the remaining half of the population lives in Terai or the southern plain part of Nepal. The major groups of the population can also be classified into 46.5 per cent Hindu caste group, 35 per cent Indigenous, 12.6 per cent Hindu low caste Dalit, and 4.4 per cent Muslim (CBS, 2014). A rapidly increasing urban population, 29 per cent higher than the rural population in 2001-2011, decreasing rural homogenous settlements, and increasing aging population shows that the population composition is rapidly changing in Nepal (Regmi, 2014). Nepal's diversity is rooted in the different languages, castes, religions, and ethnicities (Koirala, 2010). However, the ruling caste groups often presented Nepal's diversity as a threat to the national unity, integrity, and sovereignty (Onta, 1996). From 1950 until the recent past, the Nepali political and education system presented multiculturalism as one of the major threats to its national unity (Nepal National Education Planning Commission (NNEPC), 1956).

Education has both positive and negative faces as education both mitigates and contributes to violence and conflicts (Bush \& Saltarelli, 2000; Smith \& Vaux, 2003; Davies, 2010; Dhungana, 2020). Education can maintain conflict or jeopardize peace through uneven distribution of education, using education as a means of cultural repression, and to manipulate history for political purposes, promoting self-worth and segregating education to maintain inequality,

Journal of Contemporary Issues in Education, 2021, 16(1), pp. 3-22.

(c) Author(s), Creative Commons Attribution 4.0 (CC BY 4.0) licence

http://ejournals.library.ualberta.ca/index.php/JCIE 
inferiority, stereotypes, violence and othering (Bush \& Saltarelli, 2000; Dhungana, 2020). Davies (2010) argued that before or during conflicts, education is often used as a weapon of conflict, to reproduce normalcy, and promote biased values/histories, however eventually by interrupting cultural norms it enables people to be more resilient in post-conflict societies. Thus, on the basis of how it is used and designed, education as a state apparatus can promote both violence and peace.

Modern education in Nepal, based on its approach to responding to Nepal's diversity, can be categorised into two phases: cultural homogenisation under the discourse of 'unity in diversity' in 1956-1990, and 'cultural de-homogenisation' with the promotion of the value of 'celebrating diversity' since 1990 to date. I used 'homogenisation' as a situation where the state adapted a centralised system to promote monoculture, one language-Nepali, one religion-Hinduism-, and one political system-monarchy, that undermined the diversity of the multicultural context. Adapting Bank (1995), I approached multicultural education as a process of nurturing the value of peace, human rights, democracy, and justice, "arising out of the civil rights movements of the 1960s-1970s" (p. 391).

It is assumed that conflicts are resolved through peace agreements and the role of education is underestimated (Georgieva, 2017; Hymel \& Darwich, 2018; Smith \& Vaux, 2003) as existing peace education literature provides limited examples of how education contributes to building positive peace in a complex multicultural context. Further, the role of education in addressing the root causes of conflicts implanted through the hegemonic political systems and institutions is overlooked in academia. Hence, this paper aims to enhance the understanding of how peace education can redress the socio-political conflicts that homogenised education fuelled historically. It draws on literature that critically analyses education as a means to promote negative and positive peace, derived from Galtung (1969), by imparting knowledge, skills, and values to interrupt and transform historical domination (Bajaj, 2015; 2019). Similarly, this paper has taken a reference of critical theoretical perspectives on education and curriculum as a mechanism for communicating normative meanings and knowledge to students to promote the dominant ideology and culture (Bourdieu \& Passeron, 1990; Apple, 2004).

The centralized education system in Nepal until 1990 used education to uphold cultural homogenization under the discourse of 'unity in diversity'. For understanding the role of education during two different political systems over the last 60 years in Nepal, I analysed the contents of Nepal's relevant education policies, curricula, and textbooks. Using Bank's (1995) five criteria of multicultural education, I analysed the relevant contents of The Nepal National Education Planning Commission (NNEPC, 1956), the National Education System Plan (MoE, 1971), the lower secondary education curriculum 1973 (HMG, 1973), the National Curriculum Framework 2007 (MoE, 2007), the Basic Education curriculum, 2013 (MoE, 2013) and the Social Studies textbook (MoEST, 2013). I also explored how multicultural education including peace was integrated in the education system since the establishment of the multi-party democratic system in 1990. I used a summative content analysis technique which usually tracks

Journal of Contemporary Issues in Education, 2021, 16(1), pp. 3-22. (c) Author(s), Creative Commons Attribution 4.0 (CC BY 4.0) licence http://ejournals.library.ualberta.ca/index.php/JCIE 
keywords or content followed by interpretation of the underlying context (Hsieh \& Shannon, 2005) and which is also flexible for dealing with qualitative as well as quantitative nature of information (White \& Marsh, 2006). The content analysis places particular focus to the lower secondary-level, grade five to eight, social-studies curriculum, curricular objectives, and proposed content outlines. Bank (1995) presented five premises of multicultural education 'content integration, the knowledge construction process, prejudice reduction, equity pedagogy and empowering school culture' (p. 392). I adapted these premises to analyse how far the education plan, curriculum, and textbooks promote multicultural education.

\section{Education as Cultural Homogenization: Promoting the State Ideology of "Unity in Diversity"}

Historically, Nepal has dealt with diversity differently across different times and contexts. Considering diversity as a threat to national unity, solidarity, and sovereignty, the NNEPC (1956) and the National Education Commission (NEC) (MoE, 1971) set 'unity in diversity' as one of the major goals of education to unite the Nepali society through one language (Nepali), one political system (Monarchy) and one religion (Hinduism). Dealing with these threats, the educational goals were set to promote monoculture under the discourse of 'unity in diversity,' the Nepali state ideology. However, the ideology of unity in diversity overlooked the possible risks of violence that cultural homogenisation promoted through the monocultural education could bring about (Sen, 2006). I echo with Conversi (2010), who defines cultural homogenisation as a state-led policy that imposes the dominant culture on the rest of the citizenry, which is a top-down process where the state seeks to nationalise the mass.

Homogenisation is to preserve and distribute,through intuitions like schools, the dominant class's cultural capital and maintain social control (Apple, 2004). Moreover, schools are criticised for breeding inequality as they promote an elitist culture (Bourdieu \& Passeron, 1990). Culturally homogenised education promotes cultural particularism.

Cultural particularism presents multiculturalism as a threat to the elite groups and thus the ruling class promotes cultural homogenisation for creating an integrated society by means of a common language, currency and common cosmopolitan behaviour (Nemetz \& Christenson, 1996). Beginning from the 1950s, Nepal's monarchy used education to build national unity in the multicultural context. This state ideology emerged when King Prithvi Narayan Shah, 1723-1775 AD unified multiple small kingdoms located in the northern Himalayan hills between India and China. The unification was based on four ideas:

The unquestioning power and authority of the Hindu King of Gorkha [sic]; the supremacy of the Hindu ethos in national life; social integration through Hindu social system based on caste divisions; and recognition of Nepali as the language of government, administration and in more recent time, education (Gurung, 2003).

The state ideology is reflected in the Nepali education system and the government actively promoted the state ideology through mass education.

Journal of Contemporary Issues in Education, 2021, 16(1), pp. 3-22. (c) Author(s), Creative Commons Attribution 4.0 (CC BY 4.0) licence http://ejournals.library.ualberta.ca/index.php/JCIE 
The NNEPC 1956 was the first education-related national report that guided Nepali education policies. This report presented diversity as a problem. One of the primary-level curricular objectives of education set forth by NNEPC was: to develop civic competencies, attitudes of responsibility and cooperation, appreciation of our struggle for democracy and the contributions of our national heroes, a feeling of national unity and solidarity, a desire for self-sufficiency and willingness to help oneself, etc. (NNEPC, 1956). In this objective, the national heroes referred to werethe King and his ancestors. These objectives reflect two key values: national unity and democratic participation. Highlighting the need for national unity, the report stated: "If the younger generation is taught to use Nepali as the basic language, then other languages will gradually disappear, and greater national strength and unity will result" (p. 93).

In 1960, the King took over the power from the elected government led by political parties and introduced a partyless Panchayat system. The King introduced the Panchayat (which literally means the "Council of Elders"), which is rooted to Nepal's caste system assuming that the Western-style multi-party democratic system is not suitable in the Nepali context (Smith, 1967). The King ruled Nepal under the Panchayat system from 1960 until the political parties were able to establish a multi-party democratic system with ceremonial monarchy in 1990.

The Panchayat system introduced its education policy, the National Education System Plan (NESP) 1971-1976. The NESP promoted single nationhood and consolidated the loyalty and faith to the dominant class as presented below:

NESP developed based on certain issues included in the context of this plan. Politicisation of the traditional multi-ethnic Nepalese societies will not lead to national solidarity and independent sovereign nationhood without a central guidance in planned socialisation (p.14). Panchayat system that aims at coordinating the various economic and social interests, harmonising diverse multi-lingual traditions into a single nationhood, consolidating the loyalty and faith in the Crown. The goal of education was to create citizens who are loyal to the nation, by widely integrating multilingual traditions into the national unity (MoE, 1971, p. 21).

A major objective of education is to produce citizens who are loyal to the nation, the Crown and national independence, and who remain ever alert and active toward their rights and duties under the Panchayat System, author's translation from Nepali).The educational objectives are reflected in the subject-related objectives of the curriculum. For example, the Social Studies subjects are meant to increase awareness about different caste and ethnic groups; develop an attitude of respect despite the differences in caste, religion, and class;

Journal of Contemporary Issues in Education, 2021, 16(1), pp. 3-22. (c) Author(s), Creative Commons Attribution 4.0 (CC BY 4.0) licence http://ejournals.library.ualberta.ca/index.php/JCIE 
develop the feeling of love and respect towards the Crown and the nation. (MoE, 1971, author's translation from Nepali).

The NESP proposed education aimed to unify Nepal's cultural diversity through the Nepali language, Hindu values, and monarchy. This has also reflected in education participation as, until the 1950s, most of the students were from the high caste and class and the lower caste students were implicitly denied formal education in Nepal (Stash \& Hannum, 2001). Presentation of multiple cultures, language and cultural diversity and freedom of speech, mainly the citizens' ability to demand for freedom, democracy, and justice were presented as the threat to the national unity and the King. Moreover, the NESP presents an example of how a national education plan developed with the involvement of intellectuals is influenced by the political interest of the ruling class. This knowledge construction process primarily guided and sponsored by and for the ruling class undermines the interest of the majority caste and ethnic groups like Dalits, indigenous nationalities and the Madheshi.

The national goals and objectives of the curriculum were indifferent to reduce the culturally rooted prejudice. For example, the prejudice that a person 'not speaking Nepali' can't be a good citizen. Rather, the curriculum was to foster strong discipline, character and morale support for the ruling class and popularise their cultural norms as the standard norms.It is utopic to expect to have any room for equity pedagogy in an education system mainly geared towards promoting 'popular culture', the culture of ruling class. The NESP clearly mentioned that political freedom is not useful for the society that is traditional and multi-cultural in nature before it is united with the centre-led socialization process. Similarly, school education was used for socialising the diverse cultures towards 'unity' against the voice raised for freedom, democracy, and justice and respect for diversity, considered threats to the national unity and the Crown. Thus, schools were not empowered to provide education that could foster multiculturalism. The Panchayat used the mainstream knowledge to create citizens who are loyal to the nation and king by widely integrating multilingual traditions into the national unity.

A state's curriculum is generally guided by political ideology, which is mostly enshrined in the Constitution, and often such curricula are implemented in a hidden form (Apple, 2004). The 1962 Constitution placed monarchy at the centre of the government and all other systems revolved around it (Smith, 1967), providing the king with the absolute power to seize all parliamentary power and appoint or remove judges of the Supreme Court (King, 2014). In 1960s, The King introduced a Panchayati political system wherein the central role of education was to build faith in the Panchayat system and the state ideology of 'unity in diversity.' The Panchayat regime also "encouraged the National language and culture to neutralize the tide of capitalism and communism in the neighbourhood" (Dahal, 2006, p. 22). Hence, the Panchayati monocultural education was disempowering for the students of minority groups, and for those who were unable to speak Nepali national language.

The primary objective of education was to "produce citizens who, with full faith in the country and the Crown, will conduct themselves in accordance with the Panchayat system and to meet

Journal of Contemporary Issues in Education, 2021, 16(1), pp. 3-22.

(c) Author(s), Creative Commons Attribution 4.0 (CC BY 4.0) licence

http://ejournals.library.ualberta.ca/index.php/JCIE 
the manpower requirements of development through the spread of scientific and technical education" (MoE, 1971, p. 94). In the introduction, the NESP raised the emerging issue of politicising a multi-ethnic society, which was considered a major threat to national solidarity and the independent sovereign nation. The nationalisation of the past under the Panchayat system created a sensibility of a shared history through a centralised school curriculum and curricular materials (Onta, 1996). The NESP continued the homogenised education; however, it replaced the value of democratic participation and introduced a party-less Panchayat system. Panchayati politics of hegemony and denial of multicultural as well as multilingual reality was imposed through the education policy (Upadhayaya, 2010). The NESP stressed that education should support the Panchayat system's aim to harmonise the cultural diversity to the single nationhood. Education during the Panchayat system was instrumental in strengthening and justifying the Panchayat system and its founder, the king as the protector of Nepalese unity in diversity (Onta, 1996). Hence, education was crafted as a means of 'centrally guided socialisation', which fosters as well as harmonises diverse multilingual traditions into a single nationhood, loyalty and faith in the crown and accelerates socio-economic progress. Caddell (2007) also recognised that the Panchayat system promoted cultural homogenisation through education. The Social Studies Curriculum was geared towards understanding Nepal's political system and national contribution of the Monarchy, understand Panchayat political system, and being loyal to the nation, Crown, and Royal family. Government initiated the Back to Village National Campaign (BVNC) to mobilise to support the Panchayat system. The BVNC mobilized a Panchayat supported student organization for humiliating the opposition leaders (Baral, 1980). The grade 8 Social Studies textbook presents the notion of 'education for national unity'. King Mahendra and King Birendra's (1944-2001) messages are presented on the first page of all textbooks. King Mahendra, in his opening message, highlighted that education should be able to address children's need for vocational education so the students are able to contribute towards national integrity and follow the Panchayat system. Grade 8 textbook published in 1973 comprised eight units. The first unit introduced and justified the Panchayat system; the second introduced different levels of Panchayati institutions; and the third glorifiedthe Great King, the unifier of Nepal, Father of the Nation (Father of Democracy) and National hero, the Founder of the Panchayat System. Units four to seven described the Panchayat system and institutions, and the last unit, 'Back to Village National Campaign (BVNC)', was introduced as an innovative idea to modernize the rural community and promote the Panchayat System (HMG, 1973).

In addition, other subject curriculum, for example history,was to reinforce the glory of the Monarchy (HMG, 1973). Similarly, the Panchayat education system also fully used to explain the negative sides of multi-party democratic political system to rationalise why the King had to dissolve the elected parliament and introduce the party-less Panchayat system in Nepal(Smith, 1967). In addition, a separate subject was introduced to inject the value of the monarchy-led Panchayat system in Nepal. Hence, the Government mainly led by the monarchy, cemented, and institutionalised cultural homogenisation through education and de-valued the cultural diversity.

Journal of Contemporary Issues in Education, 2021, 16(1), pp. 3-22. (c) Author(s), Creative Commons Attribution 4.0 (CC BY 4.0) licence http://ejournals.library.ualberta.ca/index.php/JCIE 
Panchayatize education discouraged other languages other than Nepali as the medium of instruction (Dahal, 2000). Mandelbaum (2014) criticised the cultural homogenisation process as a fantasy, a constructed project of modernity, which is generally imposed through the national education system. Homogenisation is an instrument to preserve the Hindu ideology in Nepal (Gurung, 2003) as educationglorified the King and Panchayat system while presenting multiple cultures as unimportant or less valuable, in line with education's function to devalue the dominant cultures for ideological purpose (Apple, 2004).

Against the aim of the Panchayati education system, many youths trained under the Panchayat education system actively participated in the anti-Panchayat political movement. As a student (1980-1990) of Panchayati education system, I never felt that I should stand and fight for the Panchayat political system, but rather participated in anti-Panchayat protests organised in and around school. Nepal's 'centrally guided and homogenised education' could not retain monarchy as the symbol of unity, national integrity, and prosperity. It is because the state was often unable to stop the ongoing countervailing tendencies and oppositional practices present in society and in schools (Apple, 2004). Although homogeneity was the major doctrine of the Panchayat education system, some forms of counter-practices remained alive and vibrant in different forms. The racial homogeneity may create conditions for inequality for a variety of reasons (Edwards, 2016). Such doctrine of promoting cultural homogenisation, could also lead society towards ethnic cleansing and genocide (Conversi, 2010). Despite the continued implementation of monocultural education Panchayat failed to suppress peoples' increased aspiration to democracy and freedom. As aresult of massive protests against the Panchayat system in 1990, a multi-party system was established. This system provided Nepal an opportunity to revisit its state ideology 'unity in diversity' and monocultural education.

\section{A Shift Towards Education for Peace}

In 1990, political parties established a multi-party democratic system because of the people's movement against the Panchayat system. The 1990 multiparty democratic Constitution opened the scope to revisit the state ideology of 'unity in diversity'. The Constitution included values of a multi-party democratic system of governance, which included the principles of democracy and human rights. These rights were also reconfirmed at the international level when Nepal became party to the United Nations Convention on the Rights of the Child (UNCRC), the International Covenant on Economic, Social and Cultural Rights and the International Covenant on the Civil and Political Rights. As a result, there emerged scope for de-homogenising education.

Further, a National Education Commission (1992) report recommended to replace the homogenised curriculum and introduce rights-based education in Nepal (Smith, 2015). Nepal committed to the Constitution and by signing the UNCRC, acknowledged that providing education for all is the duty of the state. Article 4 of the Constitution clearly sets out that "Nepal is a multi-ethnic, multilingual, democratic, independent, indivisible, sovereign, Hindu and constitutional monarchical kingdom". This was obvious because the political leaders, the key actors in Constitution making process, were deeply bound up within them by virtue of

Journal of Contemporary Issues in Education, 2021, 16(1), pp. 3-22.

(c) Author(s), Creative Commons Attribution 4.0 (CC BY 4.0) licence

http://ejournals.library.ualberta.ca/index.php/JCIE 
dependence and submission which were expected to be replaced by liberalism, human rights providing more autonomy to schools (Carney \& Rappleye, 2011). The National Education Commission 1992 proposed to revise the curriculum in line with the changed Constitution and the political context.

It is evident that structural and cultural violence towards minorities leads towards direct violence (Galtung, 1969). After more than three decades of the implementation of centralised monocultural education, Nepal experienced a decade-long Maoist-armed insurgency (19962006). Monocultural education played its part in fuelling the structural and cultural violence by fostering the cultural homogenisation process in Nepal. Later, the National Education Commission report criticised that the monocultural education fuelled the under-current of revolt in the academic community (MoE, 1992). Maoists used the people's dissatisfaction against the homogenisation to justify their violent insurgency (Van Wessel \& van Hartum, 2013).The Maoists had 40-point demands, which included abolishing the monarchy, ending racial exploitation and suppression, stopping discrimination against the downtrodden and backward people, and providing equal status for all (Thapa, 2003).

Since 1990s, the issue of recognizing diversity, as raised by marginalized ethnic groups and indigenous nationalities, has become a key political issue (Davis, Phyak, \& Bui, 2012). The Education sector's long homogenisation efforts de-valued and excluded the Dalits, indigenous population and Madheshi communities. The women, indigenous and Dalit youths happened to join the violent insurgency as there was high level of poverty and inequalities, and the state failed to deliver development (Leve, 2007). Maoist leaders played with the emotions and sentiments of the marginalized population deprived from the development. However, in 2006, the armed insurgent party, the Maoists and the Government of Nepal signed the Comprehensive Peace Accord and expressed their commitment to carry out progressive restructuring of the state to resolve existing class-based, ethnic, regional and gender related issues. Further the parties agreed to address the problems related to women, Dalit, indigenous people, Madheshi, oppressed, neglected and minority communities and backward regions by ending discrimination based on class, caste, language, gender, culture, religion, and region (CPA, 2006).

The changed political system and the Maoist armed insurgency created space for a reexamination of the education system. The Maoist insurgency raised demands for peace and absence of direct, structural, and cultural violence (Galtung \& Fischer, 2013) and created a favourable situation to launch a new initiative to foster peace in Nepal. As the result, the Government formulated a new national curricular framework (NCF) in 2007 and moved to include diversity, democracy and human rights, and justice in school education.

\section{Fostering multicultural values in post-conflict Nepal}

The National Curriculum Framework (NCF) 2007 recognised the need to protect human rights, child rights, peace, gender, respect of diversity and social inclusion. NCF highlighted the role of diversity in empowering all communities including the disadvantaged and marginalised communities (MoE, 2007). Below is an excerpt from the NCF 2007:

Journal of Contemporary Issues in Education, 2021, 16(1), pp. 3-22.

(c) Author(s), Creative Commons Attribution 4.0 (CC BY 4.0) licence

http://ejournals.library.ualberta.ca/index.php/JCIE 
In the context of 21 st century human rights, child rights, peace, gender and social equity, population education and environment conservation including global information and communication technology have become the emerging needs (p. 6). Development of curriculum, teachers, evaluation system should be balanced and in proper coordination with multi cultural sensitivity, economic condition, social structure, norms and values and nature and lifestyle of Nepalese people (p. 28).

The NCF acknowledged the need for promoting multiple languages through education and ensure child rights to get primary education in their mother language (p.13) and realised the need to have an inclusive system in curriculum and provided additional support for the disadvantaged children such as the girls, Dalits, children with disabilities, working children, children affected from armed conflict, and street children (p.14). The NCF set the following goals, relevant to the multicultural education:

- Help prepare citizens with good conduct and morals for a healthy social and collective lifestyle by promoting supreme human values inherent in each individual, national culture and dignity, social values, beliefs and experience.

- Consolidate social integrity through socializing individuals.

- Be insightful to social equality and justice and develop conduct accordingly to help create inclusive society

- Foster the feelings of peace, friendship, goodwill, tolerance and fraternity in local, national and international context and adopt ones conduct accordingly; and prepare citizens capable enough to resolve any kind of conflict.

- Prepare citizens respectful to nation, nationality, democracy, judicious, creative, self-honored, respecting others and feel proud of being Nepali. (MoE, 2007, p. 31)

NCF opened the scope to revisit the monocultural education system which was based on the belief that the cultural diversity is a major risk to Nepalese unity, integrity, and sovereignty. Against this background, in collaboration with UNICEF, UNESCO and Save the Children, Nepal's Curriculum Development Centre initiated to integrate peace education in the national curriculum. The work begun in 2005 continued in the post-conflict context, contributing to promote the value of human rights, inclusion, and cultural diversity. In 2005-15, through a multi-year, multi-stakeholder approach, contents and values of peace, human rights, civics education, gender equality, democracy, good governance, and disarmament were integrated in school curricula. Further, the initiative could mainstream peace, human rights, and civic education in formal (primary) and non-formal curricula, and development of modules for child

Journal of Contemporary Issues in Education, 2021, 16(1), pp. 3-22. (c) Author(s), Creative Commons Attribution 4.0 (CC BY 4.0) licence http://ejournals.library.ualberta.ca/index.php/JCIE 
clubs and for in-service teacher education (Thapa, Dhungana, Mahalingum, \& Conilleau, 2010). The purpose of revisiting the centralised curriculum is to foster peace, democracy, equality, freedom, and justice in line with the 21 century's demand of society. It was impossible to challenge the state ideology without sufficient technical and financial capacity and broad-based support from the political system. Creating and including effective learning competencies in curricula and textbooks required sufficient technical backup. The support provided by the technically competent agencies such as UN and Save the Children in collaboration with the National Human Rights Commission was effective (Smith, 2015).

Peace education is used as an instrument to promote peace and coexistence in a multicultural context (Sadigbyali, 2006). It is helpful in the context where diversity is considered as a problem for national unity (Cremin \& Guilherme, 2016). In particular, critical peace education is well suited to pacify society (Noddings, 2012) and amplify the marginalised people's voices (Bajaj, 2019). Similarly, I echo Bank (1995), who argued that multicultural education is a continued educational reform movement that provides all students an equal chance to learn, empower and give voice and ultimately promotes the value of freedom, justice, and democracy. In addition, I added peace and human rights in the multicultural education, although these values might be already embedded in the concept of justice and democracy.

It was quite challenging to promote multicultural education when the different communities were engaged in political confrontations. Continuedgeneral strikescalled by various political parties, whichforced schools to remain shut for a day or more, were one of the most common forms of political violence that affected schools. Even after the end of the armed insurgency, some of the Nepalese political groups continued to attack schools, teachers, and to use students for their political purposesincluding the Maoists (Pherali, 2013). In addition to direct forms of violence, inequity - structural form of violence - is also a major concern for Nepalese schooling. The active conflict might give rise to supporting the peace education initiative. As the result, the MoE increased the content that promotes respect diversity.

Building upon Save the Children, the US's pilot initiative, and the United Nations Educational, Scientific and Cultural Organization's (UNESCO) capacity-building initiative in 2006-7, the United Nations Children's Fund (UNICEF), Save the Children, and UNESCO signed a Memorandum of Understanding (MoU) with the Curriculum Development Centre and started integrating peace education in the national school curriculum (Smith, 2012, Thapa et al., 2010). During this process, in 2014, Nepal's stakeholders developed the peace and disarmament education framework that included five broad content areas relevant to Nepal: respect and celebrate diversity; mutual respect and tolerance; affirmative communication, conflict management and non-violence; critical thinking and fostering the spirit of enquiry; and disarmament and human security. The learning objectives relevant to the multicultural education in the lower secondary and secondary level education are as follows:

\begin{tabular}{|l|l}
\hline Lower Secondary level [grade 6-8] & Secondary level [grade 9-10]
\end{tabular}

Journal of Contemporary Issues in Education, 2021, 16(1), pp. 3-22. (c) Author(s), Creative Commons Attribution 4.0 (CC BY 4.0) licence http://ejournals.library.ualberta.ca/index.php/JCIE 


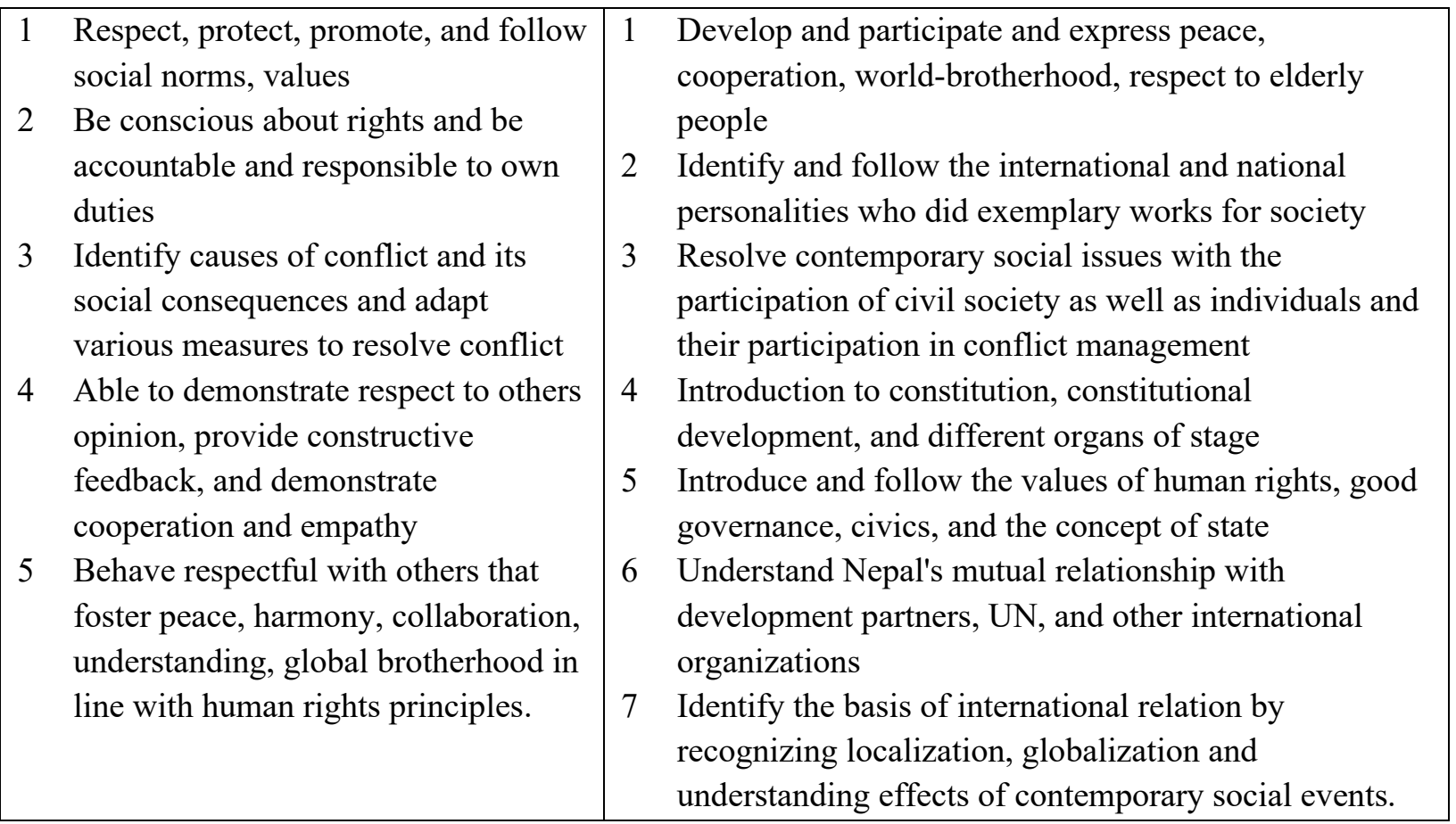

(MoE, 2013).

In the process of including peace education, Nepal applied asystematic and collaborative process, ensured participation of marginalised communities in the process and in curricular contents, aligned the government's regular curriculum revision process, used trained and committed human resources, and international experts ensured the quality of the curriculum and textbook lessons (Smith, 2015). Grade-wise learning objectives related to multicultural education and the level of relatedness is presented below:

\begin{tabular}{|l|l|l|l|}
\hline Level/Grade & No. of learning objectives & $\begin{array}{l}\text { Moderately related } \\
\text { to multicultural } \\
\text { education }\end{array}$ & $\begin{array}{l}\text { Highly related to } \\
\text { multicultural } \\
\text { education }\end{array}$ \\
\hline 6 & 27 & 7 & 5 \\
\hline 7 & 31 & 9 & 5 \\
\hline 8 & 31 & 9 & 5 \\
\hline 9 & 44 & 11 & 6 \\
\hline 10 & 38 & 13 & 4 \\
\hline Total & 171 & $49(29$ per cent $)$ & $30(15$ per cent $)$ \\
\hline
\end{tabular}

Some examples of such multicultural education related learning objectives included in the curriculum are: Identify reasons of various conflicts and find alternate ways to manage those conflicts; promote global brotherhood; promote critical and analytical communication skills;

Journal of Contemporary Issues in Education, 2021, 16(1), pp. 3-22.

(c) Author(s), Creative Commons Attribution 4.0 (CC BY 4.0) licence http://ejournals.library.ualberta.ca/index.php/JCIE 
adopt and follow peace, security, good governance, and rule of law. Among the total 171 learning objectives of grade 6-10 of social studies subject, 15 per cent of the contents are relevant to promoting multicultural education including peace.

I was involved in this process from 2005-2015 and facilitated several consultations with indigenous communities, women, human rights commission, international experts, religious leaders as well as sexual minorities. After five years substantive support received from UNICEF and Save the Children, United Nations Regional Cenre for Peace and Disarmament in Asia and the Pacific (UNRCPD) provided last mile technical assistance to the Curriculum Development Centre for integrating peace education in the curriculum through a peace and disarmament education project. The values infused through peace education initiatives are reflected in the grade 8 Social Studies textbook's preface section, for example:

At present it is important that students are loyal to the nation, internalise democratic system, and can make an inclusive society. For the development of an equitable society, students should respect diversity based on caste/ethnicity, gender, religion, culture, and region (MoEST, 2016).

The learning objectives included in school curricula further expanded in grade level curriculum. For instance, in grade 8 social studies, one-third of the learning objectivesare closely related with peace education which comprises the value of democracy, justice, peace, freedom, equality and other contents related to recognising multiple cultures, languages, religions, festivals under the scope of celebrating diversity MoEST, 2016). Based on the content analysis, I found that, of the total 104 learning objectives of the 6-8 grades, 33 are related to promotion of multi-cultural education, under the broader umbrella of peace education.

The broader umbrella of peace education eventually expanded to "peace, human rights, civics and disarmament education". The learning objectives of grades 6 to 8 are more precise and explicit. For example, three of the level-related competencies of social studiescurriculum for grade 6-8 are, "Student's at the local and global level will be able to communicate and engage with the communities different than their own in an effective and appropriate manner; identify and respect the social, geographical, and cultural diversity; respect the views of others, provide constructive feedback and express sympathy while behaving and communicating with others"(MoE, 2013, p.69). Out of the total 33 objectives, 20 objectives are to promote the value of peace, humanrights, and multicultural education. Altogether, 20 per cent of the social study curricular objectives isrelated to peace and multi-culturaleducation in grades 4 to 5 . In the case of grades 6 to 8 social studies subject, more than half of the learning objectives are relevant to multi-cultural education, peace, and human rights. Hence, the curricular objectives set in the national curriculum are sufficiently reflected in the level-related curriculum and teacher training manual included in the textbook, mainly in social studies subject. Some examples of peace, human rights and multi-cultural education-related learning objectives are:

Journal of Contemporary Issues in Education, 2021, 16(1), pp. 3-22. (c) Author(s), Creative Commons Attribution 4.0 (CC BY 4.0) licence http://ejournals.library.ualberta.ca/index.php/JCIE 
- Respect, protect, promote, and follow social norms and values.

- Be conscious about rights and be accountable and responsible to own duties.

- Identify causes of conflict and their social consequences and adapt various measures to resolve conflict.

- Be able to demonstrate respect to others opinion, provide constructive feedback, and demonstrate cooperation and empathy.

- Behave respectfully towards others to foster peace, harmony, collaboration, understanding, and global brotherhood in line with human rights principles.

(MoE, 2013).

Similar contents promoting multicultural education are also included in the grade six social studies textbook:

\begin{tabular}{|l|l|l|}
\hline Unit & Unit Name & Relevant Lessons \\
\hline 1 & We and our society & Introduction of society and community and foundation of society. \\
\hline 2 & $\begin{array}{l}\text { Our social values and } \\
\text { norms }\end{array}$ & $\begin{array}{l}\text { Our festivals, our national pride, respect diversity, our cultural } \\
\text { heritages, our religious heritages, and our national personalities. }\end{array}$ \\
\hline 3 & $\begin{array}{l}\text { Social problems and } \\
\text { solutions }\end{array}$ & $\begin{array}{l}\text { Non-discrimination, social problems, resolving social problems, } \\
\text { understanding others and peacebuilding. }\end{array}$ \\
\hline 4 & Civic awareness & $\begin{array}{l}\text { Constitution, introduction of citizenship, civic rights, duties of the } \\
\text { citizen, right to information, traffic rules, nation and state, federal } \\
\text { democratic system of governance. }\end{array}$ \\
\hline
\end{tabular}

(MoE, 2013).

Including multicultural contents and objectives in education was possible as the result of the partnership between Government of Nepal and the UN and civil society organisations, the participatory approach adapted in curriculum reform and good collaboration with the international and national civil society organisations, United Nations, National Human Rights Commission (NHRC). Similarly, thethe favourable political context also enabled the Ministry of Education to to revisit the monocultural education and include lessons that promote peace, justice, democracy, and respect diversity. This initiative, using a critical peace education approach, advanced and fostered the value of celebrating diversity and contributed to overcoming tensions fuelled by the historically constructed monocultural education.

\section{Nurturing the value of 'celebrating diversity'}

The peace education initiative, over the years, advanced towards integration of peace, human rights, and civics education in formal curriculum, mainly targeting to social studies curriculum and textbooks. In additionto the lessons related to multicultural education, the curriculum also included content related to prevention of domestic violence, social problems like child labour, awarenessofdrugs and substance abuses (MoEST, 2019).

Journal of Contemporary Issues in Education, 2021, 16(1), pp. 3-22.

(c) Author(s), Creative Commons Attribution 4.0 (CC BY 4.0) licence http://ejournals.library.ualberta.ca/index.php/JCIE 
The curricular materials included the competencies related to respecting and celebrating diversity, mutual respect and tolerance, affirmative communication skills, conflict management and disarmament and human security. Within this scope, issues related to gender equality and social justice issues were also integrated (Dhungana \& Khatiwada, 2015). When integrated in curriculum, the education system translates those competencies in the textbooks, teacher training materials and teacher training programmes. It was recommended to include the following themes and competencies in the 6-10 curriculum:

\begin{tabular}{|l|l|}
\hline Themes & Competencies \\
\hline $\begin{array}{l}\text { 1. } \\
\text { Respecting and } \\
\text { celebrating diversity }\end{array}$ & $\begin{array}{l}\text { Demonstrate appropriate behaviour on diversity with full respect for } \\
\text { others, self-respect, understanding self-dignity, social justice, and } \\
\text { positive thinking }\end{array}$ \\
\hline $\begin{array}{l}\text { 2. } \\
\text { Mutual respect and } \\
\text { tolerance }\end{array}$ & Demonstrate mutual harmony, understanding and tolerance \\
\hline $\begin{array}{l}\text { 3. } \\
\text { communication }\end{array}$ & $\begin{array}{l}\text { Communicate responsibly applying positive thinking, in a coordinated } \\
\text { manner, with mutual understanding and respect for others' opinion }\end{array}$ \\
\hline 4. Conflict management & $\begin{array}{l}\text { Recognise conflict and peace in society, manage conflict and } \\
\text { contribute to promoting peace }\end{array}$ \\
\hline 5. $\begin{array}{l}\text { Disarmament and human } \\
\text { security }\end{array}$ & $\begin{array}{l}\text { Contribute to creating a violence free society being conscious of the } \\
\text { role of disarmament and human security }\end{array}$ \\
\hline
\end{tabular}

(UNRCPD, 2015).

In line with the inputs received from various stakeholders like UNRCPD, the Ministry of Education included 3 new lessons, 23 activities and 48 pages of contents that directly contribute to redressing the tensions fuelled by the monocultural education in the past and promoting the value of peace, justice, tolerance, human rights, the elements of multicultural education. The number of new lessons, activities and number of pages included in grade 8 textbook of moral education, social studies, Nepali and English subjects are as follows:

\begin{tabular}{|l|l|l|l|}
\hline Subject & $\begin{array}{l}\text { Number of New lessons } \\
\text { included }\end{array}$ & $\begin{array}{l}\text { Total } \\
\text { Activities }\end{array}$ & $\begin{array}{l}\text { Total Pages covered the } \\
\text { activities }\end{array}$ \\
\hline Moral education & 1 & 8 & 12 \\
\hline Social studies & 1 & 6 & 13 \\
\hline Nepali & 0 & 5 & 8 \\
\hline English & 1 & 2 & 5 \\
\hline Total & 3 & 23 & 48 \\
\hline
\end{tabular}

(MoE, 2013; UNRCPD, 2015).

It is important to note that the curriculum allocated one separate unit for civics education. Similarly, lessons on fundamental rights mentioned in Nepal's Interim Constitution of 2007, universal human rights values and principles, child rights, and women's rights and the role of the Human Rights Commission are explicit in the textbooks. Lessons on peace cover broader issues such as cooperation with neighbours and different cultural groups, conflict management, and

Journal of Contemporary Issues in Education, 2021, 16(1), pp. 3-22.

(c) Author(s), Creative Commons Attribution 4.0 (CC BY 4.0) licence

http://ejournals.library.ualberta.ca/index.php/JCIE 
multi-cultural education related issues such as celebrating and respecting diversity. Dhungana and Khatiwada (2015) found that Nepal's peace education initiative implemented in the postconflict context provided an important opportunity to revisit education, so that education could reflect Nepal's multicultural reality, encourage students to resolve conflict in a non-violent manner as well as to respect and celebrate diversity.

The education reform that started after the establishment of the multi-party democratic system in Nepal gradually recognised Nepal's cultural diversity, people's rights to participate in democratic political process, value of human rights, justice, and peace. Nepal's new peace education initiative laid the foundation for multicultural education by integrating curricular objectives, lessons and other teaching tools related to peace, human rights, and democracy in education. These contents were included in discussion with local consultative groups coming from diverse groups like ethnic minorities, Dalit, indigenous groups, youth, and women (Smith, 2015). Celebrating diversity, social inclusion, and social justice, and dealing with inequality and discrimination, were the major issues discussed and integrated in social studies of grades three to eight. The multi-year (2005-15), participatory and critical peace education initiative integrated the value of diversity, peace, and justice in education in school curriculum. Further, these contents are retained in the NCF (MoEST, 2019).

The Constitution promulgated in 2015 mentioned that Nepali children can have access to education in the mother tongue, andmultilingual education will be promoted. Bajaj (2015) argues that peace education can be a useful tool to respond to issues of diverse realities, particularly in the case of those facing marginalisation. However, in many cases, education is unable to promote democratic values and human rights as teachers are not capacitated to foster such values (Long, 2018). There is a need for pedagogical strategies that disrupts dehumanisation and divisive narratives which could perpetuate violence (Gill \& Niens, 2014).

The peace, human rights and multicultural education implemented during the multi-party democratic system since 1990s has been increasing awareness among multi-cultural groups in Nepal. For example, the number of communities identified by their language has increased to 123 in the 2011 Census from 11 in the 1981 Census (CBS, 2012). Similarly, the recently increased political representation of Dalits, minority, indigenous communities, and Madheshipresents an example of how multicultural education contributes to the construction of a democratic society. These changes indicate that, with the establishment of a multi-party democratic political system in 1990, the cultural homogenisation process initiated since the 1950 s, is being revisited in Nepal. The multicultural education process initiated under the broader framework of peace, human rights, civics, and disarmament education within the scope of National Curriculum Framework 2007, contributed to cultural de-homogenisation and promoting diversity.

Changing curriculum and textbooks might be useful but the memory of the historical exclusion against the Dalits, indigenous communities, Madheshi and minority groups may not be forgotten easily. On the one hand, the peace education initiative enhances the anti-oppressive education

Journal of Contemporary Issues in Education, 2021, 16(1), pp. 3-22. (c) Author(s), Creative Commons Attribution 4.0 (CC BY 4.0) licence http://ejournals.library.ualberta.ca/index.php/JCIE 
(Heringer, 2020), which empowers teachers to address each student's unique situation. The incorporation of diversity and multiculturalism in curricular tools is useful but insufficient unless teachers are prepared to deliver these teaching tools in the classroom effectively. On the other hand, the knowledge and skills related to non-violence and cultural harmony, democracy and justicegained from education might not automatically translate into lasting behaviour of students who often show contradictory behaviour (Basabose \& Habyarimana, 2019). Despite continued efforts to foster the value of multiculturalism and diversity, unless such values are effectively inculcated in the minds of children in a sustained period, the negative effects of cultural homogenisation will be retained in the minds of the education and learners.

Hence, to reshape the bitter memory of the long process of cultural homogenisation, we might have to actively create a climate in which different views are discussed with respect and empathy and promote the culture of listening to others (Noddings, 2012). Education situated in an unequal society preserves and distributes the cultural capital of dominant cultures as school is one of the state institutions (Apple, 2004) and can help students become effective citizens in multicultural society (Bank, 1995). The Panchayat system used the monocultural education discourse of 'unity in diversity' to promote its symbolic property. However, when the Panchayat system failed to maintain its power, a new multi-party democratic political system was initiated in 1990 . The new political system created a favourable environment to redress the socio-political tensions through multicultural education. The multicultural education gained political support as it was initiated under the broader discourse of the 'peace education' project and was effective due to the engagement of technically competent partners, for example UNESCO, UNICEF, UNRCPD, Save the Children and the National Human Rights Commission. However, nurturing the value of multicultural education and peace is an unfinished project as elite control of decision-making and fear of discrimination among ethnic minorities (Strasheim, 2019), the roots of conflict, are yet to be transformed.

\section{Conclusions}

In multicultural societies education can be used to fuel social tension and conflicts by promoting values of dominant culture. The conflict fuelling function of education devalues the cultural diversity of society. Viewing diversity as a problem, Nepali education, during the partyless Panchayat system 1960-1990, promoted monocultural education for more than three decades, contributing to inter-community tensions. The Nepal experience shows that using education for cultural homogenisation in a multicultural society for the interest of the dominant class can be counterproductive for the ruling elites themselves. Further, the post-conflict context provides an opportunity for educational reform and the use of education as an instrument to promote peace by amplifying the voice of the marginalised and addressing the roots of violence (Bajaj, 2019). Such redressal process is effective when the macro-education policies provide necessary space to initiate new education initiatives, and the multiple stakeholders with relevant mandate and competencies are engaged for a sustained period, and teachers and stakeholders work together nurturing the value of 'celebrating diversity' through education. In a multicultural context,

Journal of Contemporary Issues in Education, 2021, 16(1), pp. 3-22. (c) Author(s), Creative Commons Attribution 4.0 (CC BY 4.0) licence http://ejournals.library.ualberta.ca/index.php/JCIE 
including the elements of peace and multicultural values in education, making learners and educators a critical learners of knowledge (Bank, 1995) should be continued. Sustained peace education is relevant as the risk of the negative face of education appearing and reappearing always exists. When the political context becomes favourable, the tensions and conflicts fuelled by the nationalized monocultural education can be gradually redressed through a multicultural education that enables learners to be citizens of a multicultural society.

\section{References}

Apple, M.W. (2004). Ideology and curriculum. NY: Routledge.

Bajaj, M. (2019). Conceptualising critical peace education in conflict settings. Education and Conflict Review, 2, 65-69. https://discovery.ucl.ac.uk/id/eprint/10081588

Bajaj, M. (2015). 'Pedagogies of resistance' and critical peace education praxis. Journal of Peace Education, 12(2), 154-166. https://doi.org/10.1080/17400201.2014.991914.

Bank, J.A. (1995). Multicultural education and curricular transformation. Journal of Negro Education, 64(4). https://doi.org/10.2307/2967262

Baral, L. R. (1980). Nepal 1979: Political system in crisis. Asian Survey, 20(2), 197-205.

Basabose, J. D. D., \& Habyarimana, H. (2019). Peace education in Rwandan secondary schools: Coping with contradictory messages. Journal of Peacebuilding \& Development, 14(2), 138-149. https://doi.org/10.1177\%2F1542316619846825

Bourdieu, P., \& Passeron, J. C. (1990). Reproduction in education, society and culture (4th ed.). Sage.

Bush, K. D., \& Saltarelli, D. (2000). The two faces of education in ethnic conflict: Towards a peacebuilding education for children. Available at https://www.unicefirc.org/publications/pdf/insight4.pdf

Caddell, M. (2007). Education and change: A historical perspective on schooling, development and the Nepali nation-state. In K. Kumar, \& J. Oesterheld (Eds.), Education and social change in South Asia (pp. 251-284). New Delhi: Orient Longman. Available at http://oro.open.ac.uk/2907/1/caddell-History.pdf.

Carney, S., \& Rappleye, J. (2011). Education reform in Nepal: From modernity to conflict. Globalisation, Societies and Education, 9(1), 1-9. https://doi.org/10.1080/14767724.2010.513274

Central Bureau of Statistics (CBS). (2014). Population monograph of Nepal, Vol 2 (Social demography). Kathmandu: Author. Available at Population Monograph V02.pdf (unfpa.org)

Central Bureau of Statistics (CBS).(2012). National population and housing census 2011, national report. Kathmandu: Author.

Conversi, D. (2010). Cultural homogenization, ethnic cleansing, and genocide. Oxford Research Encyclopedia of International Studies. https://doi.org/10.1093/ACREFORE\%2F9780190846626.013.139

Journal of Contemporary Issues in Education, 2021, 16(1), pp. 3-22.

(c) Author(s), Creative Commons Attribution 4.0 (CC BY 4.0) licence

http://ejournals.library.ualberta.ca/index.php/JCIE 
Comprehensive Peace Accord (CPA). (2006). Comprehensive peace accord. https://peacemaker.un.org/nepal-comprehensiveagreement2006

Cremin, H., \& Guilherme, A. (2016). Violence in schools: Perspectives (and hope) from Galtung and Buber. Educational Philosophy and Theory, 48(11), 1123-1137. https://doi.org/10.1080/00131857.2015.1102038

Dahal, D. R. (2006). Civil society groups in Nepal:Their roles in conflict and peace building.Kathmandu: UNDP. Available at https://citeseerx.ist.psu.edu/viewdoc/download?doi=10.1.1.729.3967\&rep=rep1\&type=pd $\mathrm{f}$

Dahal, R. K. (2000). Language politics in Nepal. Contributions to Nepalese Studies, 27(2), 155190.

Davies, L. (2010). The different faces of education in conflict. Development, 53(4), 491-497.

Davis, K. A., Phyak, P., \& Bui, T. T. N. (2012). Multicultural education as community engagement: Policies and planning in a transnational era. International Journal of Multicultural Education, 14(3). http://dx.doi.org/10.18251/ijme.v14i3.625

Dhungana, R.K., \& Khatiwada, H.R. (2015). Peace and disarmament education - II: Project evaluation. [Unpublished Evaluation report submitted to theUnited Nations Regional Centre for Peace and Disarmament].

Dhungana, R. K. (2020). Ethnography of school violence: A cultural perspective. Journal of Education and Research, 10(2). 125-126. https://doi.org/10.3126/jer.v10i2.32725

Edwards, L. (2016). Homogeneity and inequality: School discipline inequality and the role of racial composition. Social Forces, 95(1), 55-76. https://doi: 10.1093/sf/sow038

Galtung J., \& Fischer D. (2013). Positive and negative peace. Briefs on pioneers in science and practice, 5. Springer, Berlin, Heidelberg. https://doi.org/10.1007/978-3-64232481-9 17

Galtung, J. (1969). Violence, peace, and peace research. Journal of Peace Research, 6(3), 167191.

Gill, S., \& Niens, U. (2014). Education as humanisation: Dialogic pedagogy in post-conflict peacebuilding. Compare, 44(1), 1-9. doi.10.1080/03057925.2013.864522

Gurung, H. (2003). Trident and thunderbold: Cultural dynamics in Nepali politics.Kathmandu: Social Science Baha, 1-28.

Heringer, R. (2020). Reconceptualizing anti-oppressive pedagogy: A lesson from the other. Journal of Contemporary Issues in Education, 15(2). doi 10.20355/jcie29426

His Majesty's Government of Nepal [HMG]. (1973). Lower secondary education curriculum. Ministry of Education: Curriculum Development Centre.

Hsieh, H. F., \& Shannon, S. E. (2005). Three approaches to qualitative content analysis. Qualitative Health Research, 15(9), 1277-1288. https://doi.org/10.1177\%2F1049732305276687

Hymel, S., \& Darwich, L. (2018). Building peace through education. Journal of Peace Education, 15(3). 345-357. https://doi.org/10.1080/17400201.2018.1535475

King, A. (2014). Peace by peaceful means? A preliminary examination of Buddhist peacebuilding in post-conflict Nepal. Religions of South Asia, 8(3), 339-368.

Journal of Contemporary Issues in Education, 2021, 16(1), pp. 3-22. (c) Author(s), Creative Commons Attribution 4.0 (CC BY 4.0) licence http://ejournals.library.ualberta.ca/index.php/JCIE 
Koirala, B. (2010). Opportunities for multi-lingual education in Nepal. Journal of Education and Research, 2(1), 30-34. https://doi.org/10.3126/jer.v2i0.7620

Leve, L. (2007). 'Failed development' and rural revolution in Nepal: Rethinking subaltern consciousness and women's empowerment. Anthropological Quarterly, 80(1) 127-172. https://doi.org/10.1215/9780822377191-004

Long, J. (2018). Educational administrators' perspectives of democracy and citizenship education: Interviews with educational leaders. Journal of Contemporary Issues in Education, 13(2). https://doi.org/10.20355/jcie29349

Mandelbaum, M. M. (2014). The Gellnerian modality revisited: Towards a 'genealogy'of cultural homogenization and nation-state congruency. Ethnic and Racial Studies, 37(11), 2014-2033. https://doi.org/10.1080/01419870.2013.788728

Ministry of Education, Science and Technology (MoEST). (2019). National curriculum framework. Bhaktapur: Curriculum Development Centre.

Ministry of Education, Science and Technology (MoEST). (2014). Social studies textbook. Bhaktapur: Curriculum Development Centre.

MoE. (2015). Secondary education curricula, grade 9-10. Bhaktapur: Curriculum Development Centre.

MoE. (2013). School curriculum, grade 6-8. 68-90. Kathmandu: Ministry of Education.

MoE. (2007). National curriculum framework. Bhaktapur: Curriculum Development Centre. file://C:/Users/User/Downloads/National-Curriculum-Framework-2007-English.pdf

MoE. (1992). Report of the national education commission. Kathmandu: Author.

MoE. (1971). The national education system plan for 1971-76. Kathmandu, Nepal: Government of Nepal. https://www.moe.gov.np/assets/uploads/files/2028_English.pdf

Ministry of Education, Science and Technology (MoEST). (2016). Social studies and population education, grade 8. Kathmandu: Author.

Nemetz, P. L., \& Christensen, S. L. (1996). The challenge of cultural diversity: Harnessing a diversity of views to understand multiculturalism. Academy of Management Review, 21(2), 434-462. https://doi.org/10.2307/258668

Nepal National Education Planning Commission (NNEPC). (1956). Education in Nepal: Report of the Nepal National Educational Planning Commission. Kathmandu: Bureau of Publications, College of Education. Available at https://www.moe.gov.np/assets/uploads/files/2011_English.pdf

Noddings, N. (2012). Peace education: How we come to love and hate war. Cambridge University Press.

Onta, P. (1996). Ambivalence denied: The making of rastriyaitihas in Panchayat era textbook, Contributions to Nepalese Studies, 23(1), 213-54. http://himalaya.socanth.cam.ac.uk/collections/journals/contributions/pdf/CNAS_23_01_1 3.pdf.

Pherali, T. J. (2013). Schooling in violent situations: The politicization of education in Nepal, before and after the 2006 peace agreement. Prospects, 43, 49-67. https://doi:10.1007/s11125-012-9255-5

Journal of Contemporary Issues in Education, 2021, 16(1), pp. 3-22. (c) Author(s), Creative Commons Attribution 4.0 (CC BY 4.0) licence http://ejournals.library.ualberta.ca/index.php/JCIE 
Regmi, L. K. (2014). An overview of population growth trends of Nepal. Journal of Institute of Science and Technology, 19(1), 57-61. https://doi.org/10.3126/jist.v19i1.13828

Sadigbayli, R. (2006). Peace education as a coexistence and reconciliation tool: The context of the conflict between Armenia and Azerbaijan. Master's Capstone Thesis. University of Massachusetts.

Sen, A. (2007). Identity and violence: The illusion of destiny. Penguin Books.

Smith, M. (2015). Nepal: Lessons from integrating peace, human rights, and civic education into social studies curricula and textbooks. Paris: France: UNESCO, International Institute for Educational Planning.

Smith, M. (2012). Peace, human rights and citizenship education in Nepal: Multi-stakeholder collaboration in post-conflict curriculum reform. In Education for global citizenship. 101112. Doha: Education Above All.

Smith, T. B. (1967). The ideology of Nepal's Panchayati Raj. [Unpublished Master's degree dissertation, University of Arizona].

Smith, A., \& Vaux, T. (2003). Education, conflictand international development. London: Department for International Development.

Stash, S., \& Hannum, E. (2001). Who goes to school? Educational stratification by gender, caste, and ethnicity in Nepal. Comparative Education Review, 45(3), 354-378. https://doi.org/10.1086/447676

Strasheim, J. (2019). No 'end of the peace process': Federalism and ethnic violence in Nepal. Cooperation and Conflict, 54(1), 83-98. https://doi.org/10.1177\%2F0010836717750199

Thapa, D. (2003). Understanding the Maoist movement of Nepal. Kathmandu: Martin Chautari.

Thapa, M., Dhungana, R. K., Mahalingam, B., \& Conilleau, J. (2010). Peace by piece: Mainstreaming peace education in South Asia. Sweden: Save the Children. https://resourcecentre.savethechildren.net/library/peace-piece-mainstreaming-peaceeducation-south-asia

United Nations Regional Centre for Peace and Disarmament (UNRCPD). 2015. One year summary report of peace and disarmament education project. Author: Kathmandu. [Unpublished report].

Upadhyaya, P. K. (2010). Politics of hegemony and denial in the rhetoric of language and education policy in Nepal: A critical discourse analysis of policy documents and government sponsored textbooks (1960-2009). PhD dissertation: University of Texas.

Wessel, V. M., \& van Hirtum, R. (2013). Schools as tactical targets in conflict: What the case of Nepal can teach us. Comparative Education Review, 57(1), 1-21.

https://doi.org/10.1086/667530

White, M. D., \& Marsh, E. E. (2006). Content analysis: A flexible methodology. Library Trends, 55(1), 22-45. Available at https://www.ideals.illinois.edu/bitstream/handle/2142/3670/ResearchProcess.pdf?sequenc $\mathrm{e}=2$

Journal of Contemporary Issues in Education, 2021, 16(1), pp. 3-22. (c) Author(s), Creative Commons Attribution 4.0 (CC BY 4.0) licence http://ejournals.library.ualberta.ca/index.php/JCIE 